OPEN ACCESS

Edited by:

Syed Nasir Abbas Bukhari, Al Jouf University, Saudi Arabia

Reviewed by:

Ryoji Ito,

Central Institute for Experimental

Animals, Japan

Hal Broxmeyer,

Indiana University Bloomington,

United States

*Correspondence: Yingdai Gao

ydgao@ihcams.ac.cn

${ }^{t}$ These authors share first authorship

Specialty section:

This article was submitted to Experimental Pharmacology and Drug Discovery,

a section of the journal

Frontiers in Pharmacology

Received: 07 December 2019 Accepted: 16 March 2020

Published: 02 April 2020

Citation:

Li Y, He M, Zhang W, Yang M, Ding Y, $X u S, G u J, L i Y$, Yin J and Gao Y (2020) Antioxidant Small Molecule

Compound Chrysin Promotes the Self-Renewal of Hematopoietic Stem Cells.

Front. Pharmacol. 11:399. doi: 10.3389/fphar.2020.00399

\section{Antioxidant Small Molecule Compound Chrysin Promotes the Self-Renewal of Hematopoietic Stem Cells}

\author{
Yinghui $\mathrm{Li}^{1 \dagger}$, Mei He ${ }^{1 \dagger}$, Wenshan Zhang ${ }^{1}$, Ming Yang ${ }^{1}$, Yahui Ding ${ }^{2}$, Shiqi Xu ${ }^{1}$, Jiali Gu ${ }^{1}$, \\ Yafang $L^{1}{ }^{1}$, Jingjing Yin ${ }^{1}$ and Yingdai Gao ${ }^{1 *}$ \\ 1 State Key Laboratory of Experimental Hematology, Institute of Hematology and Blood Diseases Hospital, Chinese Academy \\ of Medical Sciences and Peking Union Medical College, Tianjin, China, ${ }^{2}$ State Key Laboratory of Medicinal Chemical Biology, \\ College of Pharmacy, Nankai University, Tianjin, China
}

There is an increasing demand for the expansion of functional human hematopoietic stem cells (hHSCs) for various clinical applications. Based on our primary screening of antioxidant small molecule compounds library, a small molecule compound C2968 (chrysin) was identificated to expand cord blood CD34 ${ }^{+}$cells in vitro. Then we further verified the optimum concentration and explored its effect on hHSCs phenotype and biological function. C2968 could significantly increase the proportion and absolute number of $\mathrm{CD}_{3} 4^{+} \mathrm{CD} 38^{-} \mathrm{CD} 4 \mathrm{f}^{+}$and $\mathrm{CD} 34^{+} \mathrm{CD} 38^{-} \mathrm{CD} 45 \mathrm{RA}^{-} \mathrm{CD} 90^{+}$cells under 2.5 $\mu \mathrm{M}$. Furthermore, the total number of colony-forming units and the frequency of LTHSCs in C2968-treated group were significantly higher than control, indicating the multipotency and long-term activity of hematopoietic stem and progenitor cells were sustained. Additionally, C2968 treatment could maintain transplantable HSCs that preserve balanced multilineage potential and promote rapid engraftment after transplantation in immunodeficient (NOG) mice. Mechanistically, the activity of chrysin might be mediated through multiple mechanisms namely delaying HSC differentiation, inhibiting ROS-activated apoptosis, and modulating of cyclin-dependent kinase inhibitors. Overall, chrysin showed good ex vivo expansion effect on hHSCs, which could maintain the self-renewal and multilineage differentiation potential of hHSCs. Through further research on its antioxidant mechanism, it may become a promising tool for further fundamental research and clinical umbilical cord blood transplantation of hHSCs.

Keywords: antioxidant, small molecule compound, chrysin, ex vivo expansion, hematopoietic stem cells, self-renewal

\section{INTRODUCTION}

Hematopoietic stem cells (HSCs) are a rare population of cells characterized by their ability to selfrenew and differentiate into multilineages in blood system to maintain adult hematopoiesis. Hematopoietic stem cell transplantation (HSCT) is a curative therapy for a number of human diseases, including hematopoietic malignancies and bone marrow failure (Alexander et al., 2018; 
Pagliuca et al., 2019). However, less than half of the patients without a suitable related human leukocyte antigen (HLA)matched donor can find an HLA-matched unrelated donor (Gragert et al., 2014). For these patients, umbilical cord blood (UCB) has become an important HSC source for allogeneic HSCT (Milano et al., 2016). The much lower immunogenicity of UCB enables transplantation despite antigen mismatch. However, the principal limitation of UCB is the low and finite number of hematopoietic stem and progenitor cells (HSPCs), which restricts their widespread use in human transplantation protocols.

To expand functional UCB HSCs available for clinical applications, researchers have been looking for suitable culture conditions to promote ex vivo expansion of HSC populations. Different combinations of recombinant growth factors and cytokines have been evaluated to promote HSCs proliferation but HSCs are prone to differentiate or even deplete during in vitro culture (Goff et al., 1998; Knapp et al., 2017). Recent studies have concentrated on applying small molecule compounds, which are gradually becoming a valuable tool for regulating the fate of stem cells. They have the virtues of simple operation, rapid and reversible effects, diverse concentrations and structures, and rapid highthroughput screening based on phenotype (Li et al., 2012; Zhang and Gao, 2016). Some of these small molecules, such as the aryl hydrocarbon antagonist StemRegenin 1 (SR1), pyrimidoindole derivative UM171, GSK-3 $\beta$ inhibitor CHIR99021 plus mTOR inhibitor Rapamycin $(\mathrm{C}+\mathrm{R})$, HDAC inhibitor nicotinamide (NAM), etc., have been shown to promote expansion of HSPCs in various degrees (Boitano et al., 2010; Huang et al., 2012; Peled et al., 2012; Fares et al., 2014). It is undeniable that small molecule compounds show the latent capacity for HSC expansion and stand a good chance of making a difference in this field. Our group has focused on drug screening for HSC manipulation, especially for safe expansion of HSC.

It's essential for stem cell homeostasis to keep a proper balance between self-renewal and differentiation during both early development and the entire life cycle. Recent evidence suggests that this balance is partly regulated by reactive oxygen species (ROS), which synchronize with metabolism, mediate the redox state of cells (Miao et al., 2013; Bigarella et al., 2014; Ludin et al., 2014). It has been reported that increased ROS levels can inhibit HSC self-renewal pathways such as Wnt- $\beta$-catenin (Undi et al., 2016; Shin et al., 2004), and activate pathways that may lead to self-renewal defects such as p38 MAPK, mTOR, and more (Ito et al., 2004; Ito et al., 2006; Yoshida et al., 2011). In fact, primitive HSCs exist in a low-oxygen niche that restricts ROS production and provides long-term protection for cells (Jang and Sharkis, 2007; Dalloul, 2013). However, some researches have proved that HSCs cultured in vitro, together with the commonly used hydrophobic materials such as polystyrene dishes or flasks, could produce excessive level of ROS, which is a well-known cause of HSC differentiation (Bigarella et al., 2014; Yu et al., 2015; Cao et al., 2016). Therefore, strategies for maintaining hypoxia milieu to mimic HSC in vivo niche are important for efficient HSC expansion approaches.

In this study, we identified a small molecule compound C2968 (chrysin) with the potential for hHSC expansion based on our primary screening of 85 antioxidant small molecule compounds in LKT laboratory database (Zhang et al., 2019). Then the optimum concentration of chrysin was determined by concentration gradient experiment. We found that primitive

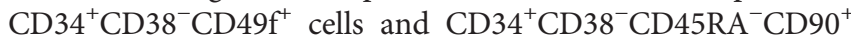
cells were proportionally and quantitatively increased after culture with chrysin. We also demonstrated that chrysin expanded stem and progenitor (PRO) cell populations with sustained multipotency and long-term functional activity. Moreover, chrysin promoted rapid human cell engraftment and preserved balanced multilineage differentiation in NOG mice transplanted with expanded cells, suggesting the potential of chrysin for the ex vivo expansion of hHSCs with functionally validated long-term repopulating capability.

\section{MATERIALS AND METHODS}

\section{Experimental Animals}

Female NOD/Shi-scid/IL2R $\gamma$ null (NOG) mice were purchased from Vital River Laboratory Animal Technology (Beijing, China), and were housed in a specific-pathogen-free condition, with free access to food and water. All animal protocols were approved by the Animal Care and Use Committee of State Key Laboratory of Experimental Hematology.

\section{Isolation of UCB CD34+ Cells and In Vitro Culture}

Samples were collected from consenting donors according to ethically approved procedures at Tianjin Central Hospital of Gynecology Obstetrics (Tianjin, China). Human CD $34^{+}$UCB cells were isolated using LS Column and QuadroMACS Separator (Miltenyi Biotec), according to the manufacturer's protocol after collecting CD34 MicroBead-labeled cells by Hetastarch (HES, B.Braun) and MACS CD34 MicroBeads (Miltenyi Biotec). The purity of the isolated CD34 ${ }^{+}$cells is about $90.58 \pm 2.97 \%(n=5)$. The absolute number of input cells was calculated based on purity and FACS data of isolated $\mathrm{CD} 34^{+}$cells and the initial seeding number in the culture $\left(1 \times 10^{4}\right.$ CD $34^{+}$cells). The absolute number of output cells was obtained by viable cell count of progeny derived from $1 \times 10^{4} \mathrm{CD} 34^{+}$cells after culture and calculation with FACS proportion data. For phenotype and function assays, $\mathrm{CD} 34^{+}$cells were cultured in HSC expansion medium consisting of Iscove's Modified Dulbecco's Medium (IMDM, Gibco) supplemented with 10\% fetal bovine serum (FBS, Gibco), $100 \mathrm{ng} / \mathrm{ml}$ human stem cell factor (SCF, PeproTech), $100 \mathrm{ng} / \mathrm{ml}$ Fms-related tyrosine kinase 3 ligand (Flt3L, PeproTech), $100 \mathrm{ng} / \mathrm{ml}$ thrombopoietin (TPO, PeproTech), and 1\% Penicillin-Streptomycin (Sigma-Aldrich). Isolated $\mathrm{CD}^{+} 4^{+}$cells were resuspended in HSC expansion medium $\left(5.3 \times 10^{4}\right.$ cells $\left./ \mathrm{ml}\right)$ before being seeded into 96 -well plates (Corning). Small molecule compounds were dissolved in dimethyl sulfoxide (DMSO, Sigma-Aldrich) and stored as stock solutions. Stock solutions were diluted to working solutions at the desired concentration by HSC expansion medium. Each well contained $190 \mu \mathrm{l}$ cell suspension $\left(1 \times 10^{4}\right.$ cells $)$ and $10 \mu \mathrm{l}$ small 
molecule compounds, which were fully blended. Cells were incubated at $37^{\circ} \mathrm{C}$ with $5 \% \mathrm{CO}_{2}$ for 7 days. For transplantation experiments, human $\mathrm{CD} 34^{+} \mathrm{CD} 38^{-} \mathrm{CD} 45 \mathrm{RA}^{-} \mathrm{CD} 90^{+}$cells were sorted into 96-well plates at 300 cells per well in $200 \mu$ l culture system, in which serum-free expansion medium (SFEM, StemCell Technologies) with $100 \mathrm{ng} / \mathrm{ml}$ hSCF, $100 \mathrm{ng} / \mathrm{ml} \mathrm{TPO}$, and $100 \mathrm{ng} / \mathrm{ml}$ Flt3L was supplemented with vehicle $(0.01 \%$ DMSO) or SR1 (Alichem, 41864) [1 $\mu \mathrm{M}]$ or Chrysin (C2968, purity $\geq 98 \%$, LKT Labs) $[2.5 \mu \mathrm{M}]$. Cells were incubated at $37^{\circ} \mathrm{C}$ with $5 \% \mathrm{CO}_{2}$ for 4 days.

\section{Flow Cytometric Analysis}

CD $34^{+}$UCB cells were seeded at $1 \times 10^{4}$ cells per well in the presence of chemical compounds. Relative percentages and absolute numbers of different HSC subsets were determined after 7 days of culture using flow cytometry. Cell phenotypes in expanded cells were stained at $4^{\circ} \mathrm{C}$ for $30-60 \mathrm{~min}$ in phosphate-buffered saline (PBS) supplemented with a combination of the following antibodies and fluorophores: APC-labeled anti-human CD34 (BD; 555824), PE-Cy7-labeled anti-human CD38 (BD; 560677), APC-H7-labeled anti-human CD45RA (BD; 560674), PerCP-Cy5.5-labeled anti-human CD90 (BD; 561557), and PE-labeled anti-human CD49f (BD; 555736). Following a wash step, stained cells were analyzed using LSRII flow cytometer (BD) and FlowJo 10 software.

\section{Colony-Forming Cell Assays}

The concentration of cultured $\mathrm{CD} 34^{+} \mathrm{UCB}$ cells was adjusted to $50 \mu \mathrm{l} / 1000$ initial cells in IMDM. Frequencies of colony-forming cells (CFC) were estimated by plating $10 \mu \mathrm{l}$ cell suspension (equivalent to 200 initial cells) in $1 \mathrm{ml} \mathrm{MethoCult} \mathrm{H} 4434$ Classic (StemCell Technologies) in six-well plates (Corning). After 14 days in culture, plates were visually scored for CFUGM, CFU-E, BFU-E, and CFU-GEMM.

\section{Cobblestone Area-Forming Cell Assays}

Cultured CD $34^{+}$UCB cells were resuspended with MyeloCult H5100 long-term culture medium (Stem Cell Technologies) supplemented with $10^{-6} \mathrm{~mol} / \mathrm{L}$ hydrocortisone (Sigma-Aldrich) and seeded on irradiated (8000 cGy) M2-10B4 bone marrow stromal cells (ATCC) in flat-bottomed collagen-coated 96-well plates at five different concentrations $(63,125,250,500,1000)$ with 12 replicates per dilution. Each well contained $50 \mu$ collagen (Stem Cell Technologies) and $1.2 \times 10^{4} \mathrm{M} 2-10 \mathrm{~B} 4$ cells. After 5 weeks of culture, all wells were scored microscopically. Wells were scored as being positive for the presence of at least one cobblestone area (CA, tightly knit group of phase-dark, angular cells in the stroma). The CA-forming cell (CAFC) frequencies were calculated with the Poisson formula from the percentage of negative wells using the LCalc software (Stem Cell Technologies).

\section{Transplantation and Monitoring of Human HSCs in NOG Mice}

At 6 to 7 weeks of age, mice were irradiated at a dose of 250 cGy $4 \mathrm{~h}$ prior to transplantation. Experiments were conducted in sodium pentobarbital-anesthetized mice. For uncultured group, freshly sorted $\mathrm{UCB} \mathrm{DAPI}^{-} \mathrm{CD} 34^{+} \mathrm{CD} 38^{-} \mathrm{CD} 45 \mathrm{RA}^{-} \mathrm{CD} 90^{+}$cells were counted and resuspended in 300 cells/25 $\mu$ PBS per mouse, and injected into mouse tibiae. For small molecules or DMSO-treated groups, 300 sorted $\mathrm{DAPI}^{-} \mathrm{CD} 34^{+} \mathrm{CD} 38^{-} \mathrm{CD} 45 \mathrm{RA}^{-} \mathrm{CD} 90^{+}$cells were cultured for 4 days in serum-free expansion system with the presence of C2968 or SR1 or DMSO as previously described. The expanded bulk-cell cultures were washed by PBS and injected into mouse tibiae in $25 \mu \mathrm{l}$ PBS. Human cell chimerism was analyzed at 4, 8 , and 12 weeks post-transplantation in the peripheral blood and 16 weeks post-transplantation in the injected side and opposite side of bone marrow, using FITC-labeled anti-human CD45 (BD; 555482). Multilineage reconstitution was analyzed in bone marrow using APC-Cy7-labeled anti-human CD33 (BioLegend; 366613), PerCPCy5.5-labeled anti-human CD19 (BD; 561295), PE-Cy7-labeled anti-human CD3 (BD; 557851), PerCP-Cy5.5-labeled anti-human CD56 (BD; 560842), APC-labeled anti-human CD235a (BD; 561775), and PE-labeled anti-human CD41a (BD; 557297).

\section{Single Cell PCR}

The following four populations were collected by Influx flow cytometry (BD) after culture: HSCs (CD34 ${ }^{+} \mathrm{CD} 38^{-} \mathrm{CD} 45 \mathrm{RA}^{-} \mathrm{CD} 90^{+} \mathrm{CD} 49 \mathrm{f}^{+}$), HSPCs $\left(\mathrm{CD} 34^{+} \mathrm{CD} 38^{-}\right)$, multipotential progenitor cells (MPPs, $\mathrm{CD}^{+} 4^{+} \mathrm{CD} 38^{-} \mathrm{CD}^{-} 5 \mathrm{RA}^{-} \mathrm{CD}^{-}{ }^{-}$) and progenitor cells (PROs, $\mathrm{CD} 34^{+} \mathrm{CD} 38^{+}$). Total RNA was extracted from each population using a CellsDirect One-Step qRT-PCR Kit (Invitrogen) according to the manufacturer's instructions. Briefly, 50 cells from each population were sorted directly into a mixture of CellsDirect $2 \times$ Reaction Mix, $0.2 \times$ TaqMan Assay Mix (Applied Biosystems), and SuperScript III RT/ Platinum Taq Mix (Invitrogen). Reverse transcription (RT) and specific target amplification (STA) were serially performed with the following parameters: $15 \mathrm{~min}$ at $50^{\circ} \mathrm{C}, 2 \mathrm{~min}$ at $95^{\circ} \mathrm{C}$, and 18 cycles of $95^{\circ} \mathrm{C}$ for 15 $\mathrm{s}$ and $60^{\circ} \mathrm{C}$ for $4 \mathrm{~min}$. Preamplified cDNA was then diluted with TE buffer (1:5) and subjected to real-time PCR. Briefly, a BioMark 96.96 Dynamic Array (Fluidigm) was used and the PCR parameters were: 10 min at $95^{\circ} \mathrm{C}$, followed by 40 cycles of $15 \mathrm{~s}$ at $95^{\circ} \mathrm{C}$ and $60 \mathrm{~s}$ at $60^{\circ} \mathrm{C}$. Data were analyzed using BioMark Real-Time PCR Analysis Software (Fluidigm, USA).

\section{Statistical Analysis}

All data are presented as the mean \pm standard deviation (SD) and all statistical analyses were done using the software Graphpad Prism version 7.0 (GraphPad Software, Inc., La Jolla, CA, USA). Statistical differences were evaluated using two tailed Student's t-test, with significance at $\mathrm{p}$ values $\leq 0.05$.

\section{RESULTS}

\section{Identification of the Optimum Working Concentration of Chrysin}

Based on our preliminary screening of 85 antioxidant small molecule compounds in database of LKT laboratory (Zhang et al., 2019), $0.5 \mu \mathrm{M}$ C2968 was initially screened out as an active candidate compound. To investigate the optimum concentration of C2968, primary human $\mathrm{CD} 34^{+}$cells isolated from UCB were seeded into 96-well plates $\left(1 \times 10^{4}\right.$ cells per well $)$ in expansion medium supplemented with SCF, TPO, and Flt3L. C2968 was 
added at a concentration gradient. The cells were cultivated for 7 days, then the mixture of expanded cells were analyzed by flow cytometry. We identified C2968 as a candidate promoter of HSPCs self-renewal, with effective concentrations of 0.5 to $10 \mu \mathrm{M}$ when tested for its ability to stimulate the expansion of a more primitive HSPC populations, CD $34^{+} \mathrm{CD} 49 \mathrm{f}^{+}$cells. The proportion of CD $34^{+} \mathrm{CD}_{49 \mathrm{f}^{+}}$cells was positively correlated with the concentration of C2968. As for the absolute number, the best effect was obtained at $2.5 \mu \mathrm{M}$, which induced a 2.6-fold increase in the absolute number of $\mathrm{CD} 34^{+} \mathrm{CD} 49 \mathrm{f}^{+}$cells when compared with control group (DMSO) (Figure 1A). Therefore, the optimum working concentration of chrysin was identified as $2.5 \mu \mathrm{M}$.

\section{Chrysin Treatment of UCB CD34 ${ }^{+}$Cells In Vitro Led to Preferential Expansion of Primitive HSCs}

It is known that CD34, CD38, CD90, CD45RA, and CD49f are common cell surface markers for identification of human HSCs and $\mathrm{PRO}$ cells in vitro and in vivo, and the measure of different combination of these markers is a close estimate of HSPCs (Notta et al., 2011). To further evaluate the ability of C2968 to expand HSPCs in vitro, we compared the impacts of C2968, SR1, and Control on outputs of UCB CD $34^{+}$cells in expansion medium for 7 days. The absolute numbers and percentages of HSPCs and HSCs were determined according to their immunophenotypes: $\mathrm{CD} 34^{+} \mathrm{CD} 38^{-}$(HSPCs), CD $34^{+} \mathrm{CD} 38^{-} \mathrm{CD} 49 \mathrm{f}^{+}$(HSCs) and $\mathrm{CD} 4^{+} \mathrm{CD} 38^{-} \mathrm{CD} 45 \mathrm{RA}^{-} \mathrm{CD} 90^{+}$(HSCs). The total outputs of $\mathrm{CD}_{3} 4^{+}$cells were significantly increased after culture, in which Con (0.01\% DMSO), SR1, and C2968 expanded 2.8-, 14.4-, and 7.2-fold greater than input respectively (Figure 1B). As for CD $34^{+} \mathrm{CD} 38^{-}$cells, both SR1 and C2968 promoted a higher percentage and absolute number than Con or the uncultured same lot HSPCs, with better performance in the presence of SR1. As for the more primitive subsets, $\mathrm{CD} 34^{+} \mathrm{CD} 38^{-} \mathrm{CD} 49 \mathrm{f}^{+}$cells and $\mathrm{CD} 34^{+} \mathrm{CD} 38^{-} \mathrm{CD} 45 \mathrm{RA}^{-} \mathrm{CD} 90^{+}$cells, it was proportionally more abundant when C2968 was present. Both SR1 and C2968 achieved significantly greater HSC quantities, with no significant difference
A

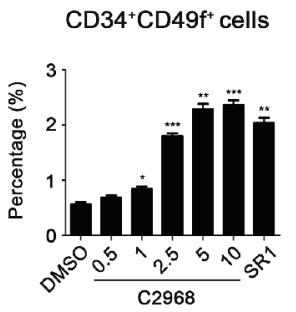

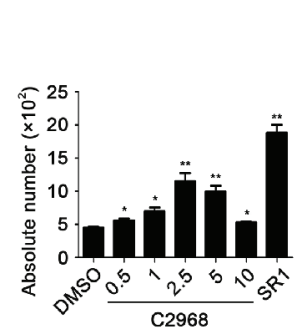

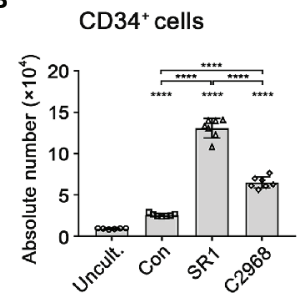

D
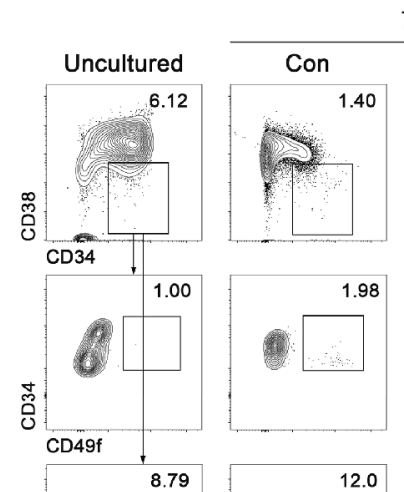

7 days in culture
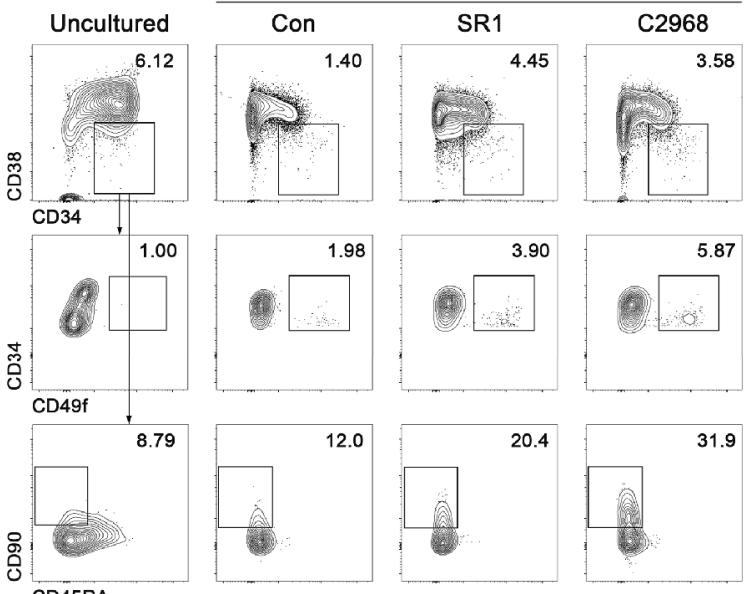
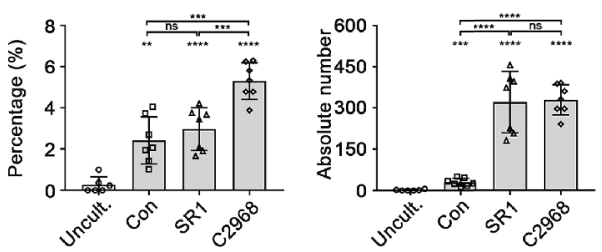

CD34+CD38-CD45RA-CD90 cells

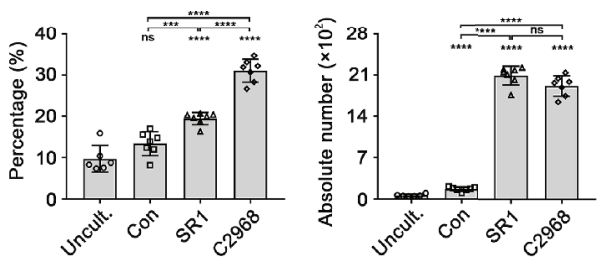

FIGURE 1 | Chrysin promoted in vitro expansion of primitive human hematopoietic stem and progenitor cells. (A) The percentages and absolute numbers of $\mathrm{CD}_{3}{ }^{+} \mathrm{CD}_{49 \mathrm{f}^{+}}$cells after 7 days in cultures supplemented with concentration gradient $(0.5,1,2.5,5$, and $10 \mu \mathrm{M})$ of $\mathrm{C} 2968(\mathrm{n}=5)$. The concentration of SR1 was $1 \mu \mathrm{M}$. (B) Quantification of total input and output CD34 $4^{+}$cells in culture $\left(n=7 ; n=6\right.$ for uncultured cells). UCB CD34 $4^{+}$cells $\left(1 \times 10^{4}\right)$ were seeded in the beginning of the culture. (C) The percentages and absolute numbers of CD34 $4^{+} \mathrm{CD} 38^{-}, \mathrm{CD} 34^{+} \mathrm{CD} 38^{-} \mathrm{CD} 49 \mathrm{f}^{+}$, and $\mathrm{CD} 34^{+} \mathrm{CD} 38^{-} \mathrm{CD} 45 \mathrm{RA} \mathrm{A}^{-} \mathrm{CD} 90^{+}$cells derived from uncultured $\mathrm{CD}_{4} 4^{+}$cells or after 7 days in cultures supplemented with Con [dimethyl sulfoxide (DMSO) 0.01\%], SR1 (1 $\left.\mu \mathrm{M}\right)$, and C2968 $(2.5 \mu \mathrm{M})(\mathrm{n}=7 ; \mathrm{n}=6$ for uncultured cells). All data represent the means \pm SD. Compared with uncultured group unless specified, ${ }^{*} p<0.05,{ }^{* *} p<0.01,{ }^{* * *} p<0.001,{ }^{* * * *} p<0.0001$ and $n s$, no significance by two-tailed unpaired t-test. $\mathrm{O}, \square, \Delta$ and $\Delta$ represent a single data point in Uncultured (Uncult.), Con, SR1 and C2968 groups respectively. (D) Representative FACS profiles of $\mathrm{CD} 34^{+} \mathrm{CD} 38^{-}, \mathrm{CD} 34^{+} \mathrm{CD} 38^{-} \mathrm{CD} 49 \mathrm{f}^{+}$, and $\mathrm{CD} 34^{+} \mathrm{CD} 38^{-} \mathrm{CD} 45 \mathrm{RA}^{-} \mathrm{CD} 90^{+}$populations derived from total live cells in uncultured and cultured CD34 ${ }^{+}$cells. 
between two compounds (Figures 1C, D). These findings indicated that chrysin supported preferential expansion of primitive human HSCs in vitro.

\section{Chrysin Treatment Sustained Multipotency and Long-Term Activity of HSPCs In Vitro Culture}

One major challenge of HSC expansion ex vivo is that the culture of HSCs results in a loss of multipotency. So we next asked whether cells treated with C2968 have the ability to emerge multiple lineage cells after culture. We performed CFC assay after 7 days of culture and approximately 1/50th of the resulting populations (about 200 starting CD $34^{+}$equivalent) were transferred to semisolid differentiation medium for another 14 days to allow colony formation. C2968-treated cells showed a prominent colony-forming potential of granulocyte and macrophage (GM) when compared to control. A comparable increase was also observed in granulocyte-erythrocytemacrophage-megakaryocyte (GEMM) colonies, which reflected the function of MPPs, when treated with C2968 instead of SR1. As for erythroid colonies, the number of BFU-E and CFU-E were almost the same between C2968 and SR1 groups (Figure 2A). Representative morphological images of different types of colonies are shown in Figure 2B. These results indicated that chrysin retained the capacity of HSPCs to differentiate into multilineages in cell cultures.

We also assessed the long-term functional capacity of C2968treated cells in CAFC assay. Cultured UCB CD $34^{+}$cells were planted in flat-bottomed collagen-coated 96-well plates preadded with M2-10B4 stromal cells at limiting doses (63, 125, $250,500,1000$ cells). The culture lasted for 5 weeks and half of the H5100 medium was changed every week during this period. LDA revealed that $0.46 \%$ ( 1 in 217) of C2968-treated CD34 ${ }^{+}$cells had long-term activity, which was closer to $0.56 \%$ ( 1 in 179) of SR1 as compared with $0.17 \%$ ( 1 in 581) of Control (Figure 2C). These results indicated that chrysin maintained the identity and long-term viability of cultured HSPCs without blocking differentiation. Together, these observations showed that our chrysin mediated in vitro $\mathrm{CD} 34^{+}$cell culture technique enabled HSPCs expansion with sustained multipotentiality.

\section{Chrysin Retained Human UCB HSC Engraftment Capacity and Multilineages Differentiation Potential in NOG Mice}

Xenotransplantation into immunodeficient mice has been the gold standard assay to detect the function of HSCs in vivo. To further expand on our observation that chrysin promoted expansion of human UCB CD34 $4^{+}$cells and examine its effect on hematopoietic reconstitution, we conducted transplantation assay in severe combined immunodeficient NOD/Shi-scid/ IL2R $\gamma^{\text {null }}$ (NOG) mice (Figure 3A). For uncultured group, 300 human UCB $\mathrm{CD} 34^{+} \mathrm{CD} 38^{-} \mathrm{CD} 45 \mathrm{RA}^{-} \mathrm{CD} 90^{+}$cells were freshly sorted and transplanted directly into NOG mice. For compoundtreated groups, the same amount of cells was sorted and cultured in clinically suitable conditions using SFEM with C2968, SR1, or vehicle control (DMSO) for 4 days. Then the cultured progeny derived from 300 HSCs were transplanted to recipients by intramedullary injection $(n=5)$. C2968-treated cells showed slightly higher level of human $\mathrm{CD} 45^{+}$cells engraftment in peripheral blood of recipient mice than that of uncultured group at the time point of 4 or 12 weeks post-transplantation. At week 8, the engraftment achieved significantly higher than uncultured or control group following treatment with C2968. However, SR1 group only showed a higher engraftment than uncultured group at week 8 . These results indicated that chrysin might promote rapid engraftment after transplantation in vivo (Figure 3B). To explore the long-term reconstitution and migration of transplanted cells, the implantation rates in bone marrow of the injection side (IF) and non-injection side (BM) were evaluated at 16 weeks post-transplantation. There would be some slight distinction between compound-treated groups and others if we focus on positive engraftment with higher donor chimerism rate. As for the injection side (IF), human $\mathrm{CD} 45^{+}$ engraftment of all recipients in C2968 group achieved over 20\%, as was the case in SR1group, while 4/5 mice in control and 3/5 mice in uncultured group achieved over $20 \%$. As for the non-injection side (BM), the engraftment trends were consistent with IF, with $3 / 5$ in C2968 and SR1 group, 2/5 in control, and 1/5 in uncultured group achieving over 20\% (Figure 3C). We also observed that C2968treated cells could differentiate into multiple lineages including myeloid $\left(\mathrm{CD} 45^{+} \mathrm{CD} 33^{+}\right)$, T lymphoid $\left(\mathrm{CD} 45^{+} \mathrm{CD} 3^{+}\right)$, natural killer cell $\left(\mathrm{CD} 45^{+} \mathrm{CD} 56^{+}\right)$, megakaryocyte $\left(\mathrm{CD} 45^{-} \mathrm{CD} 41 \mathrm{a}^{+}\right)$, and erythoid $\left(\mathrm{CD} 45^{-} \mathrm{CD} 235 \mathrm{a}^{+}\right)$after transplantation without significant difference compared to uncultured cells (Figures 3D, E). Quantification of B lymphoid differentiation in engrafted mice confirmed a more comparable reconstitution characteristics of C2968-treated and uncultured HSPCs (Figure 3D). Accordingly, this finding suggested that chrysin might promote rapid engraftment after transplantation, which is good for faster recovery of hematopoietic reconstitution, and sustain transplantable HSCs that preserve homing and balanced multilineage potential during culture.

\section{Chrysin May Promote Self-Renewal of HSCs by Maintenance of Quiescence and Inhibition of Differentiation Through Multiple Pathways}

Under steady-state conditions, HSCs stay in dormancy featured with slow cell cycle, such as quiescent phase (Pietras et al., 2011). In reaction to external stimulus, HSCs quit the G0 phase and make a variety of fate choices, such as self-renewal, multilineage differentiation, apoptosis or aging, which are controlled by stem cell intrinsic regulators as well as external modulators mainly provided by microenvironment (Wilson et al., 2009; NakamuraIshizu et al., 2014). To assess potential changes in proliferation and differentiation related gene expression in HSCs after C2968 treatment, we performed single cell PCR comparing different HSPC subsets sorted from UCB CD34 ${ }^{+}$cells cultured for 7 days with C2968 and those with Control (0.01\%DMSO). Each sample was assayed by PCR to detect expression levels of 95 genes. Approximately one third of these genes were found to be upregulated following C2968 treatment in all four cell populations (Figure 4A). The mRNA profiling revealed that the cell cycle 
A

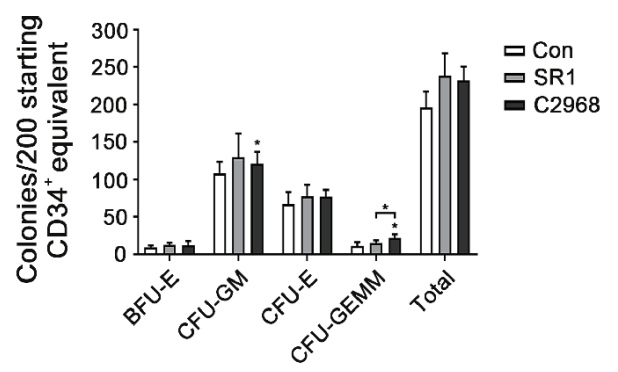

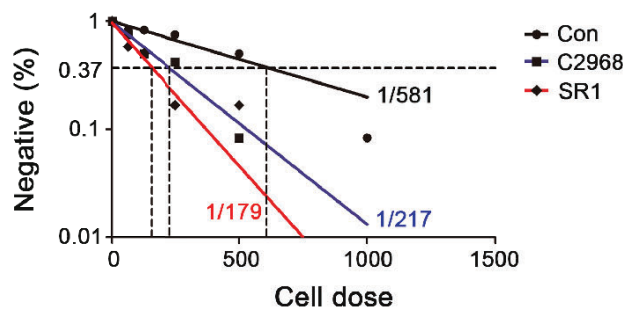

B

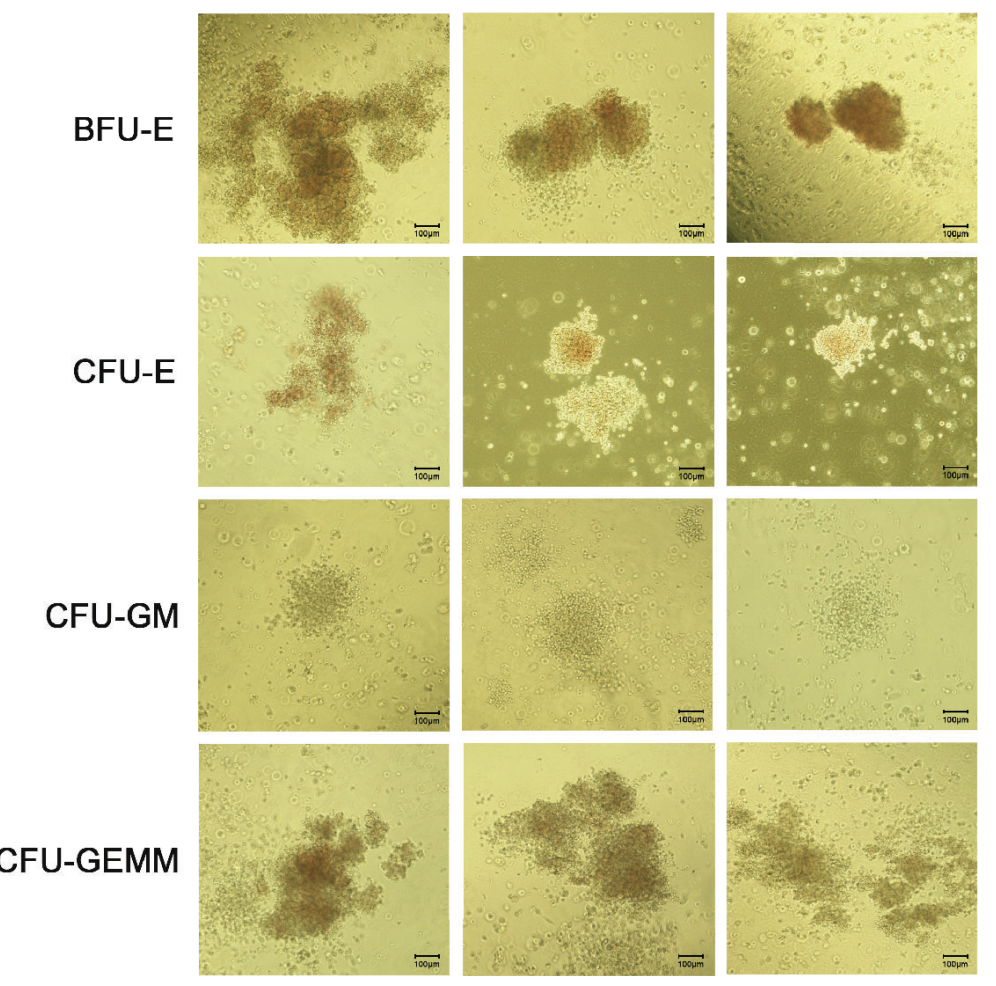

FIGURE 2 | Chrysin-treated CD34+ cells sustained in vitro multiple-differentiation potential and long-term hematopoietic capacity in culture. (A) Colonies derived from multipotent progenitor cells (BFU-E, burst-forming unit-erythroid; CFU-GM, colony-forming unit-granulocyte/macrophage; CFU-E, colony-forming uniterythrocyte; CFU-GEMMs, colony-forming unit-granulocyte/erythrocyte/macrophage/megakaryocyte) after 14 days in H4434 methylcellulose culture ( $\mathrm{n}$ = 4). (B) Representative morphological images of CFU colonies described in (A). (C) Frequency of long-term repopulating cells within Con (DMSO 0.01\%), SR1 (1 $\mu$ M), or C2968 $(2.5 \mu \mathrm{M})$ cultures measured by LDA. Positive well was defined as having more than one cobblestone-like primitive hematopoietic area. All data represent the means \pm SD. Compared with control unless specified, ${ }^{*} p<0.05$ by two-tailed unpaired t-test.

inhibitor p19, which participated in the regulation of HSC quiescence by inhibiting cell cycle transition of G0/G1 (Hilpert et al., 2014), exhibited 22-fold increase in gene expression in C2968treated HSCs $\left(\mathrm{CD} 34^{+} \mathrm{CD} 38^{-} \mathrm{CD} 45 \mathrm{RA}^{-} \mathrm{CD} 90 \mathrm{CD} 49 \mathrm{f}^{+}\right)$compared to the control group (Figure 4B). Moreover, HoxB4 has been shown to be a strong positive regulator of HSC self-renewal (Antonchuk et al., 2002; Beslu et al., 2004), and we found that HoxB4 expressed at a significantly higher level in C2968-treated HSCs compared with control (Figure 4A). Nuclear Receptor Subfamily 4 Group A Member 2 (NR4A2) has been proved to regulate differentiation, proliferation and migration of various stem cells (Sirin et al., 2010;
Maijenburg et al., 2012), and NR4A2 knockdown inhibited ROSactivated autophagy-dependent apoptosis in stem cells (Shi et al., 2017). C2968 treatment resulted in significant down-regulation of pro-apoptotic NR4A2 by 13-fold in HSCs, which might result in HSC self-renewal and expansion. The level of differentiation-related transcription factors, such as MNDA and HEY1, were significantly reduced by 337- and 217-fold respectively in HSCs (Figure 4B). C 2968 -treated HSPCs (CD $34^{+}$CD $\left.38^{-}\right)$, MPPs $\left(\mathrm{CD} 34^{+} \mathrm{CD} 38^{-} \mathrm{CD} 45 \mathrm{RA}^{-} \mathrm{CD} 90^{-}\right)$, and PROs $\left(\mathrm{CD} 34^{+} \mathrm{CD} 38^{+}\right)$had significantly increased expression of lineage-priming factors, including HEY1, GATA3, CEBPA, and CEBPD by 51-, 5-, 9-, 
A

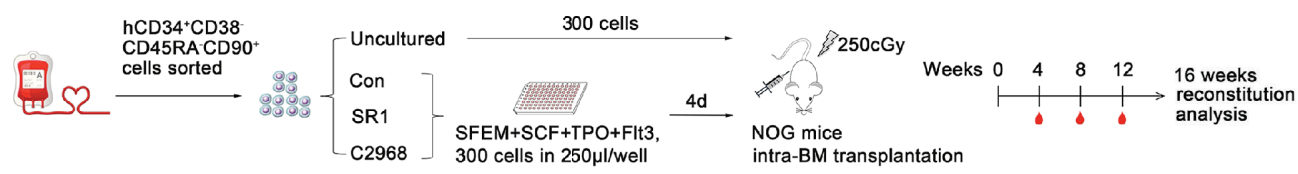

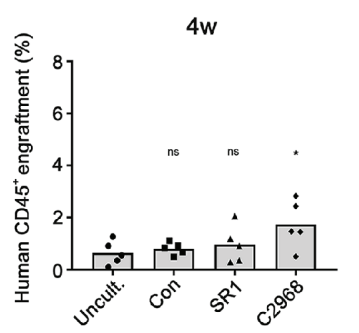

C

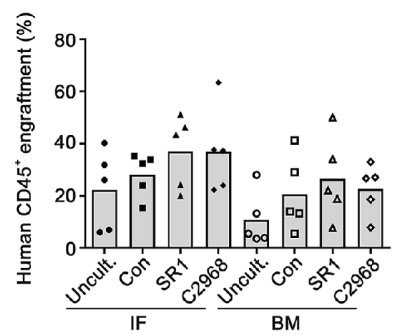

E

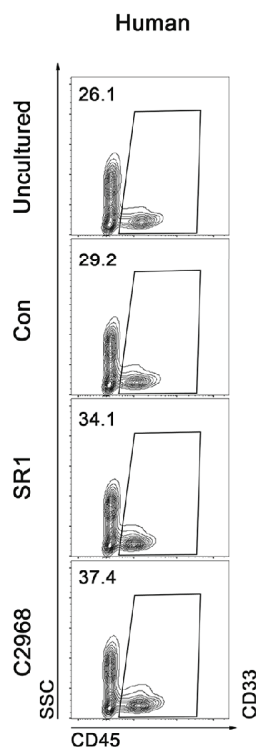

$8 w$

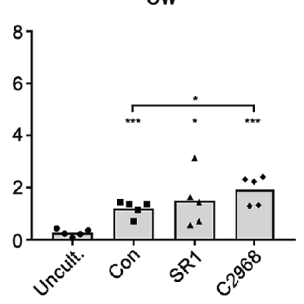

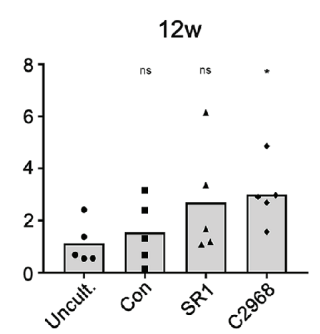

D

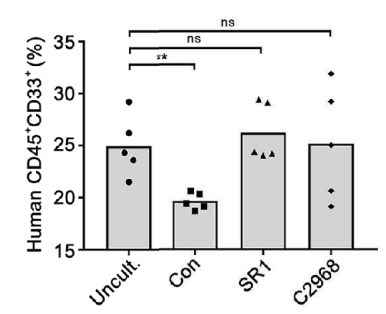

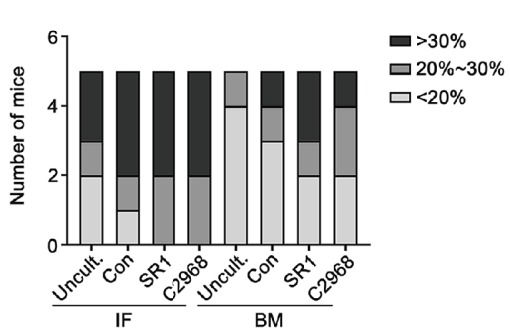
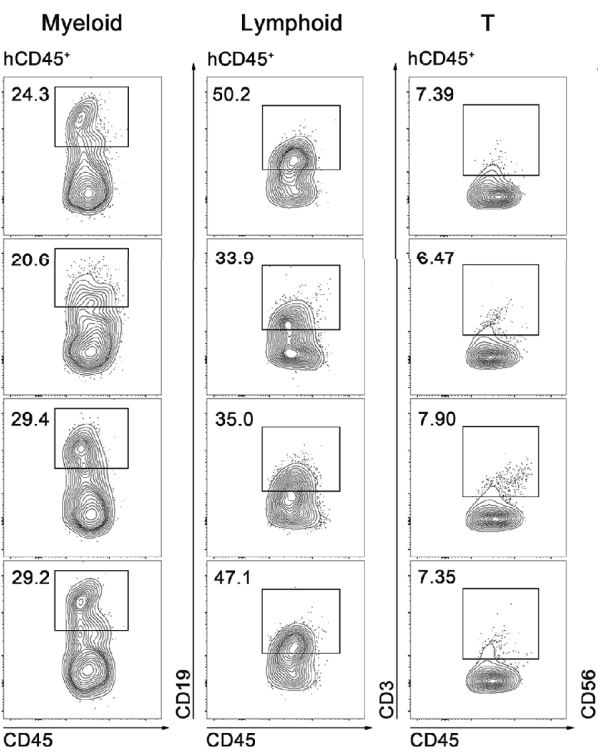
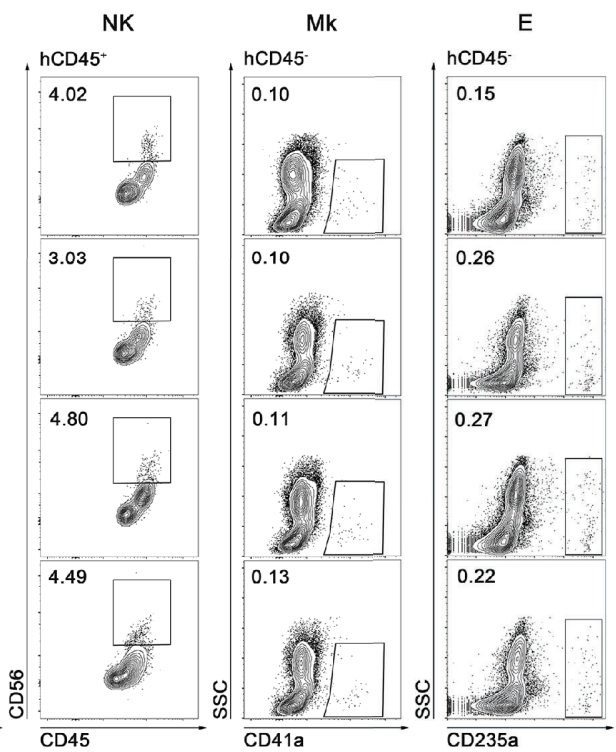

FIGURE 3 | Analysis of the effect of chrysin treatment on human hematopoietic cell engraftment and reconstitution in NOG mice. (A) Transplantation strategy with uncultured or ex vivo expanded human $\mathrm{CD} 34^{+} \mathrm{CD} 38^{-} \mathrm{CD} 45 \mathrm{RA} \mathrm{A}^{-} \mathrm{CD} 90^{+}$cells. Uncultured cells were transplanted into $\mathrm{NOG}$ mice on day 0 and cultured cells derived from 300 input cells were transplanted in to NOG mice on day 4. (B) Levels of human cell engraftment in peripheral blood (PB) of NOG mice at 4, 8, or 12 weeks post-transplantation. ( $\mathrm{n}=5$ mice per group) (C) Levels of the engrafting human cells ( $\mathrm{hCD} 45^{+}$) in the injection side bone marrow (IF) and the opposite side bone marrow (BM) at 16 weeks post-transplantation. Number of mice at different engraftment levels (<20\%; 20\% 30\%; > 30\%) in each group were shown. (D) Levels of the reconstituting myeloid $\left(\mathrm{hCD} 45^{+} \mathrm{CD} 33^{+}\right)$and lymphoid $\left(\mathrm{hCD} 45^{+} \mathrm{CD} 19^{+}\right)$in the injection side and the opposite side bone marrow at 16 weeks post-

transplantation. (E) Representative flow cytometric profiles of the engrafting human CD45 ${ }^{+}$cell and myeloid, lymphoid, T lymphocyte (hCD45 ${ }^{+}$CD3 ${ }^{+}$), natural killer cell $\left(\mathrm{NK}, \mathrm{hCD} 45^{+} \mathrm{CD} 56^{+}\right)$, megakaryocyte $\left(\mathrm{Mk}, \mathrm{hCD} 45^{-} \mathrm{CD} 41 \mathrm{a}^{+}\right)$, and erythroid $\left(\mathrm{E}, \mathrm{hCD} 45^{-} \mathrm{CD} 235 \mathrm{a}^{+}\right)$reconstitution in BM 16 weeks post-transplantation. All data represent the means $\pm \mathrm{SD}$. Compared with uncultured group unless specified, ${ }^{\star} \mathrm{p}<0.05,{ }^{\star \star \star} \mathrm{p}<0.001$, ${ }^{\star \star \star \star} \mathrm{p}<0.0001$ and ns, no significance by two-tailed unpaired t-test. $\mathbf{\square}, \mathbf{\Delta}$ and $\bullet$ represent a single data point in Uncultured (Uncult.), Con, SR1 and C2968 groups respectively in (B, D). $\boldsymbol{\square}$, $\mathbf{\Delta}$ and $\bullet$ represent a single data point of IF in Uncult., Con, SR1 and C2968 groups respectively while $\bigcirc, \square, \Delta$ and $\diamond$ represent those of BM in (C). 

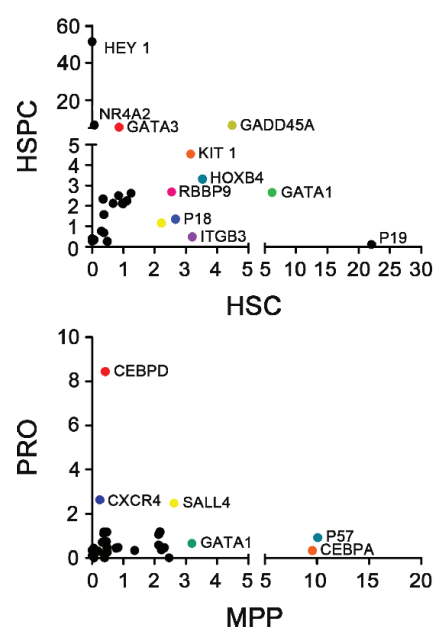

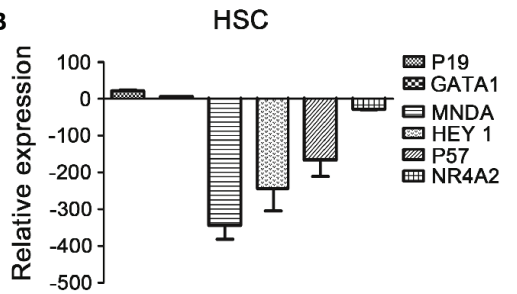

MPP

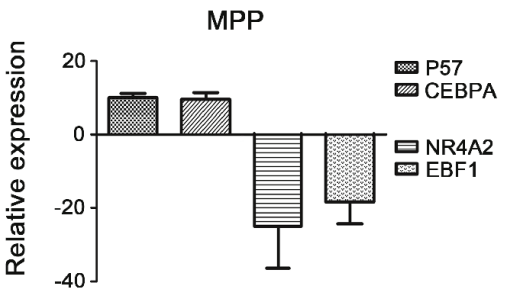

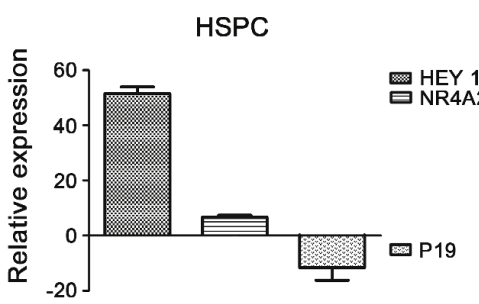

PRO

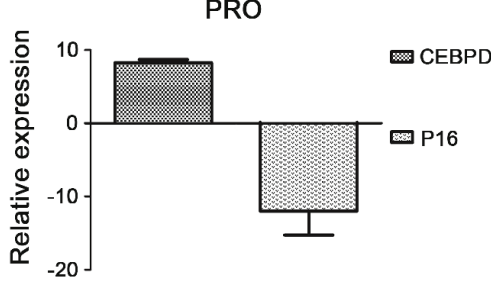

FIGURE 4 | Differential expression analysis of the genes related to hematopoiesis in cultured hematopoietic cells with or without chrysin treatment. (A) Scatter plot of mRNA profile showing upregulated genes in cultured HSCs (26 genes), HSPCs (26 genes), MPPs (28 genes), and PROs (26 genes) with C2968 treatment. The genes exhibiting significant changes in expression compared with the control group are labeled $(p<0.001)$. (B) Fold changes of relative mRNA expression of the most significant upregulated or downregulated genes in cultured HSCs, HSPCs, MPPs, or PROs with C2968 treatment. All data were normalized to the expression levels in control (DMSO 0.01\%) group. Graphs show means \pm SD ( $\mathrm{n}=100$ cells). HSCs, hematopoietic stem cells; HSPCs, hematopoietic stem and progenitor cells; MPPs, multipotential progenitor cells; PROs, progenitor cells.

and 8-fold respectively (Figures 4 A, B). Combined with our in vitro and in vivo experiments, these data may likely provide some clues about how chrysin played its role in HSC expansion. While none of the effect alone may be enough to promote the self-renewal of HSC, in combination these pathways could provide the compositions requisite for self-renewal: proliferation while blocking differentiation and preventing apoptosis.

\section{DISCUSSION}

The ex vivo expansion of UCB-derived HSCs is an increasingly popular technique to improve the therapeutic effect of HSCT. Among numerous strategies proposed, cytokines are the most fundamental amplification tool such as classic combination of SCF, TPO, Flt3-L, and interleukins (Pineault et al., 2011), others like Delta-1, Jaggad-1, SALL4, and TAT-BMI-1 (Codispoti et al., 2017). In addition, small molecules, which are basically found through mass screening, are effective agonists for in vitro amplification of UCB HSCs. For example, the latest discoveries are antagonist of PPAR-gamma GW9662 (Guo et al., 2018), inhibitor JNK-IN-8 (Xiao et al., 2019), and so on. Moreover, it is found that some co-culture systems or materials could provide a suitable microenvironment for HSC expansion, such as coculture with polyvinyl alcohol (PVA) (Wilkinson et al., 2019), zwitterionic hydrogel (Bai et al., 2019), or mesenchymal stem/ stromal cells (Costa et al., 2018). Since HSCs are deemed to grow in hypoxic environment (Takubo et al., 2010), low oxygen also plays an important role in the in vitro expansion of HSC. Under the condition of hypoxia, the expression of CXCR4 statistically increased, which means the ability of homing increased (Mohammadali et al., 2018). The use of p38-MAPK inhibitor (Bari et al., 2018) or antioxidants can maintain low ROS levels, protect HSCs from oxidative stress, and inhibit cell aging and differentiation (Ludin et al., 2014; Cao et al., 2016; Testa et al., 2016). This suggests that antioxidant small molecules may be of potential development value for expansion of HSCs, which can scavenge excessive ROS and repair oxidative damage, thus protecting the biological function of stem cells such as promoting engraftment of HSCs (Naka et al., 2008; Hao et al., 2014; Hu et al., 2014).

Based on our large-scale preliminary screening of 85 antioxidant small molecule compounds in the earlier stage (Zhang et al., 2019), we selected chrysin (C2968), which showed a better effect of expanding HSCs in vitro, for further study. Chrysin (5,7-dihydroxyflavone), a kind of natural flavone, exists in a number of plant extracts including propolis and honey. It is one of the most widely used herbal active ingredient in Asian countries. Nowadays, chrysin has become a valuable candidate exhibiting with multiple biological activities such as antioxidant, anti-inflammatory, anti-allergic, antidiabetic, antibacterial, and so on (Kasala et al., 2015; Mani and Natesan, 2018). Researchers have investigated the structureactivity relationship of chrysin to clarify the mechanism of action of chrysin, suggesting its effect on multiple signaling pathways such as Wnt, NF-אB, and PIK3 (Kasala et al., 2015; Mani and Natesan, 2018), which are also closely related to stem cells regulation. In recent years, there are a growing number of researches on chrysin and its derivatives. Some progress has been made in the effect of chrysin on the promotion of mesenchymal 
stem cell proliferation and maintenance of human adiposederived stem cells stemness (Deldar et al., 2017; Menon et al., 2018). However, in the field of hematopoiesis, the effect of chrysin on HSCs has not been reported.

In this study, we demonstrated that chrysin was effective in the ex vivo expansion of human UCB HSCs especially more primitive $\mathrm{CD}_{4} 4^{+} \mathrm{CD} 38^{-} \mathrm{CD}_{49 \mathrm{f}^{+}}$and $\mathrm{CD} 34^{+} \mathrm{CD} 38^{-} \mathrm{CD} 45 \mathrm{RA}^{-} \mathrm{CD} 90^{+}$cells. A comparable increase in GM and GEMM colonies in CFC assay reflected that chrysin promoted the self-renewal ability of HSPCs meanwhile retained the capacity to differentiate. It's known that a high dose of functional hematopoietic PRO cells, which often measured as CFU-GM, in the UCB graft predict an increased likelihood of successful engraftment, and faster times to neutrophil and platelet recovery (Avery et al., 2011). An increased frequency of LT-HSCs in CAFC assay suggested that chrysin expanded HSCs with long-term activity in culture. The in vivo data further supported chrysin played a part in promoting rapid engraftment after transplantation and retaining human cell engraftment ability and multilineage hematopoiesis capacity without bias. Single cell PCR analysis suggested that the increase in the number of functional HSCs was assumed to be the result of chrysin inhibiting differentiation and preventing apoptosis. It is known that CDKIs control the cell cycle directly through inhibiting cell cycle entry, which involve in the regulation of HSC quiescence and play an important role in maintenance of HSCs. We found that the expression of the Ink4 family member of cyclin-dependent kinase inhibitors (CKIs) p19 (Hilpert et al., 2014) increased markedly in C2968-treated HSCs, meanwhile the Kip family member of CKIs p57 (Matsumoto et al., 2011) showed different trends in C2968-treated HSCs and MPPs. It suggested that chrysin may help to preserve a quiescent, multipotential HSC pool that intermittently yielded multipotent PROs with robust proliferative potential to sustain hematopoiesis and short-term rescue. In addition, we found that a strong positive regulator of HSC selfrenewal HoxB4 (Antonchuk et al., 2002; Beslu et al., 2004) was highly expressed in C2968-treated HSCs. At the differentiation level, chrysin treatment resulted in reduced expression of differentiationrelated transcription factors such as human hematopoietic cell specific nuclear protein MNDA, which is associated with myeloid lineage differentiation and HSC quiescence (Xie et al., 1998; Lu et al., 2018), and Notch signaling downstream effector HEY1 (Sharff et al., 2009) in HSCs. On the contrary, chrysin-treated HSPCs, MPPs, and PROs had significantly increased expression of lineage-priming factors, including HEY1, GATA3, CEBPA, and CEBPD. Mechanistically, nuclear receptor transcription factor NR4A2 knockdown inhibited ROS-activated autophagy-dependent apoptosis in stem cells (Shi et al., 2017) and NR4A2 was also a limiting factor of the proliferation of HSCs (Sirin et al., 2010). Chrysin treatment resulted in reduced expression of pro-apoptotic NR4A2 in HSCs, which may result in HSC self-renewal and expansion. The molecular mechanism underlying the pleiotropic activities of chrysin was diverse, which may involve combinations of multi-levels of hematopoietic cell signaling pathways.

\section{CONCLUSION}

Ex vivo expansion of UCB-derived HSCs without causing differentiation into mature cells is considered to be an efficient procedure that is able to alter clinical treatments by making available UCB units and improving transplantation-related outcomes. Accordingly, cytokine combinations, addition of small molecules, $\mathrm{O}_{2}$ level, co-culture systems, as well as gene manipulation of HSCs can have effects on their expansion and growth. However, past many efforts mainly target single or limited pathways and often lead to lineage bias or expansion of PRO cells or limited LT-HSCs. We believe that the real way out in the future is to target multiple pathways required for maintaining HSCs through the combinations of different molecules or methods, thus resulting in expansion of functional LT-HSCs. As a promising antioxidant small molecule, chrysin-treated hHSCs could maintain long-term hematopoiesis and differentiate into multilineages of hematopoietic cells in immunodeficient mice, which provided evidence that chrysin induced unique ex vivo expansion of hHSCs without carcinogenicity or severe toxicological effects. Taken together, we herein provide a potential approach for promoting self-renewal of UCB-derived HSCs ex vivo, which provides research basis and available choice for expansion strategies combination.

\section{DATA AVAILABILITY STATEMENT}

All datasets generated for this study are included in the article/ supplementary material.

\section{ETHICS STATEMENT}

The studies involving human participants were reviewed and approved by Tianjin Central Hospital of Gynecology Obstetrics. The patients/participants provided their written informed consent to participate in this study. The animal study was reviewed and approved by Animal Care and Use Committee of State Key Laboratory of Experimental Hematology. Written informed consent was obtained from the individual(s) for the publication of any potentially identifiable images or data included in this article.

\section{AUTHOR CONTRIBUTIONS}

$\mathrm{MH}$ performed research, interpreted the data, and wrote the article. WZ prepared UCB CD34 ${ }^{+}$cells. JG, SX, YFL, JY, and YD performed research. MY carried out work on mice. YHL was responsible for critical reading of the manuscript and important intellectual content. YG was responsible for the study concept, design, and execution of the research, interpretation of data, and revision of the draft paper. 


\section{FUNDING}

This work was supported by grants from the Ministry of Science and Technology of China (Nos. 2016YFA0100600 and 2017YFA0104900), the National Natural Science Foundation of

\section{REFERENCES}

Alexander, T., Farge, D., Badoglio, M., Lindsay, J. O., Muraro, P. A., Snowden, J. A., et al. (2018). Hematopoietic stem cell therapy for autoimmune diseases - clinical experience and mechanisms. J. Autoimmun. 92, 35-46. doi: 10.1016/j.jaut.2018.06.002

Antonchuk, J., Sauvageau, G., and Humphries, R. K. (2002). HOXB4-induced expansion of adult hematopoietic stem cells ex vivo. Cell 109, 39-45. doi: 10.1016/s0092-8674(02)00697-9

Avery, S., Shi, W., Lubin,M., Gonzales, A. M., Heller, G., Castro-Malaspina, H., et al. (2011). Influence of infused cell dose and HLA match on engraftment after double-unit cord blood allografts. Blood 117, 3277-3285. doi: 10.1182/ blood-2010-08-300491

Bai, T., Li, J., Sinclair, A., Imren, S., Merriam, F., Sun, F., et al. (2019). Expansion of primitive human hematopoietic stem cells by culture in a zwitterionic hydrogel. Nat. Med. 25, 1566-1575. doi: 10.1038/s41591-019-0601-5

Bari, S., Zhong, Q. X., Fan, X. B., Poon, Z., Lim, A. S. T., Lim, T. H., et al. (2018). Ex vivo expansion of $\mathrm{CD} 34(+) \mathrm{CD} 90(+) \mathrm{CD} 49 \mathrm{f}(+)$ hematopoietic stem and progenitor cells from Non- Enriched umbilical cord blood with azole compounds. Stem Cells Transl. Med. 7, 376-393. doi: 10.1002/sctm.17-0251

Beslu, N., Krosl, J., Laurin, M., Mayotte, N., Humphries, K. R., and Sauvageau, G. (2004). Molecular interactions involved in HOXB4-induced activation of HSC self-renewal. Blood 104, 2307-2314. doi: 10.1182/blood-2004-04-1653

Bigarella, C. L., Liang, R., and Ghaffari, S. (2014). Stem cells and the impact of ROS signaling. Development 141, 4206-4218. doi: 10.1242/dev.107086

Boitano, A. E., Wang, J., Romeo, R., Bouchez, L. C., Parker, A. E., Sutton, S. E., et al. (2010). Aryl hydrocarbon receptor antagonists promote the expansion of human hematopoietic stem cells. Science 329, 1345-1348. doi: 10.1126/science.1191536

Cao, Y., Fang, Y., Cai, J., Li, X., Xu, F., Yuan, N., et al. (2016). ROS functions as an upstream trigger for autophagy to drive hematopoietic stem cell differentiation. Hematology 21, 613-618. doi: 10.1080/10245332.2016.1165446

Codispoti, B., Rinaldo, N., Chiarella, E., Lupia, M., Spoleti, C. B., Marafioti, M. G., et al. (2017). Recombinant TATBMI-1 fusion protein induces ex vivo expansion of human umbilical cord blood-derived hematopoietic stem cells. Oncotarget 8, 43782-43798. doi: 10.18632/oncotarget.15156

Costa, M. H. G., de Soure, A. M., Cabral, J. M. S., Ferreira, F. C., and da Silva, C. L. (2018). Hematopoietic niche-exploring biomimetic cues to improve the functionality of hematopoietic stem/progenitor cells. Biotechnol. J. 13, 1700088. doi: 10.1002/biot.201700088

Dalloul, A. (2013). Hypoxia and visualization of the stem cell niche. Methods Mol. Biol. 1035, 199-205. doi: 10.1007/978-1-62703-508-8_17

Deldar, Y., Zarghami, F., Pilehvar-Soltanahmadi, Y., Dadashpour, M., and Zarghami, N. (2017). Antioxidant effects of chrysin-loaded electrospun nanofibrous mats on proliferation and stemness preservation of human adipose-derived stem cells. Cell Tissue Bank 18, 475-487. doi: 10.1007/s10561-017-9654-1

Fares, I., Chagraoui, J., Gareau, Y., Gingras, S., Ruel, R., Mayotte, N., et al. (2014). Pyrimidoindole derivatives are agonists of human hematopoietic stem cell selfrenewal. Science 345, 1509-1512. doi: 10.1126/science.1256337

Goff, J. P., Shields, D. S., and Greenberger, J. S. (1998). Influence of cytokines on the growth kinetics and immunophenotype of daughter cells resulting from the first division of single CD34+Thy-1+lin- cells. Blood 92, 4098-4107. doi: 10.1182/blood.V92.11.4098

Gragert, L., Eapen, M., Williams, E., Freeman, J., Spellman, S., Baitty, R., et al. (2014). HLA Match Likelihoods for Hematopoietic Stem-Cell Grafts in the US Registry. N. Engl. J. Med. 371, 339-348. doi: 10.1056/NEJMsa1311707

Guo, B., Huang, X., Lee, M. R., Lee, S. A., and Broxmeyer, H. E. (2018). Antagonism of PPAR-gamma signaling expands human hematopoietic stem and progenitor cells by enhancing glycolysis. Nat. Med. 24, 360-367. doi: $10.1038 / \mathrm{nm} .4477$
China (NSFC 81870083, 81430004, 81421002, and 81970105), CAMS Innovation Fund for Medical Sciences (Nos. 2016-I2M-3008 and 2016-I2M-1-017), Tianjin Science and Technology Planning Project (No. 18ZXXYSY00010), and a SKLEH-Pilot Research Grant.

Hao, Y. W., Xu, H. M., Cheng, D. Y., Ma, Y. R., and Jing, L. (2014). Role of antioxidant in protecting the biological function of hematopoietic stem cells. Zhongguo Shi Yan Xue Ye Xue Za Zhi 22, 142-147. doi: 10.7534/j.issn.10092137.2014.01.028

Hilpert, M., Legrand, C., Bluteau, D., Balayn, N., Betems, A., Bluteau, O., et al. (2014). p19INK4d controls hematopoietic stem cells in a cell-autonomous manner during genotoxic stress and through the microenvironment during aging. Stem Cell Rep. 3, 1085-1102. doi: 10.1016/j.stemcr.2014.10.005

Hu, L., Cheng, H., Gao, Y., Shi, M., Liu, Y., Hu, Z., et al. (2014). Antioxidant N-acetyl-Lcysteine increases engraftment of human hematopoietic stem cells in immunedeficient mice. Blood 124, e45-e48. doi: 10.1182/blood-2014-03-559369

Huang, J., Nguyen-Mccarty, M., Hexner, E. O., Danet-Desnoyers, G., and Klein, P. S. (2012). Maintenance of hematopoietic stem cells through regulation of Wnt and mTOR pathways. Nat. Med. 18, 1778-1785. doi: 10.1038/nm.2984

Ito, K., Hirao, A., Arai, F., Matsuoka, S., Takubo, K., Hamaguchi, I., et al. (2004). Regulation of oxidative stress by ATM is required for self-renewal of haematopoietic stem cells. Nature 431, 997-1002. doi: 10.1038/nature02989

Ito, K., Hirao, A., Arai, F., Takubo, K., Matsuoka, S., Miyamoto, K., et al. (2006). Reactive oxygen species act through p38 MAPK to limit the lifespan of hematopoietic stem cells. Nat. Med. 12 (4), 446-451. doi: 10.1038/nm1388

Jang, Y. Y., and Sharkis, S. J. (2007). A low level of reactive oxygen species selects for primitive hematopoietic stem cells that may reside in the low-oxygenic niche. Blood 110, 3056-3063. doi: 10.1182/blood-2007-05-087759

Kasala, E. R., Bodduluru, L. N., Madana, R. M., AK, V., Gogoi, R., and Barua, C. C. (2015). Chemopreventive and therapeutic potential of chrysin in cancer: mechanistic perspectives. Toxicol. Lett. 233, 214-225. doi: 10.1016/ j.toxlet.2015.01.008

Knapp, D. J., Hammond, C. A., Miller, P. H., Rabu, G. M., Beer, P. A., Ricicova, M., et al. (2017). Dissociation of survival, proliferation, and state control in human hematopoietic stem cells. Stem Cell Rep. 8, 152-162. doi: 10.1016/ j.stemcr.2016.12.003

Li, W., Jiang, K., and Ding, S. (2012). Concise review: a chemical approach to control cell fate and function. Stem Cells 30, 61-68. doi: 10.1002/stem.768

Lu, Z., Hong, C. C., Kong, G., Assumpção, A. L. F. V., Ong, I. M., Bresnick, E. H., et al. (2018). Polycomb group protein YY1 is an essential regulator of hematopoietic stem cell quiescence. Cell Rep. 22, 1545-1559. doi: 10.1016/ j.celrep.2018.01.026

Ludin, A., Gur-Cohen, S., Golan, K., Kaufmann, K. B., Itkin, T., Medaglia, C., et al. (2014). Reactive oxygen species regulate hematopoietic stem cell self-renewal, migration and development, as well as their bone marrow microenvironment. Antioxid. Redox Signal. 21, 1605-1619. doi: 10.1089/ars.2014.5941

Maijenburg, M. W., Gilissen, C., Melief, S. M., Kleijer, M., Weijer, K., Ten Brinke, A., et al. (2012). Nuclear receptors Nur77 and Nurr1 modulate mesenchymal stromal cell migration. Stem Cells Dev. 21, 228-238. doi: 10.1089/scd.2011.0076

Mani, R., and Natesan, V. (2018). Chrysin: sources, beneficial pharmacological activities, and molecular mechanism of action. Phytochemistry 145, 187-196. doi: 10.1016/j.phytochem.2017.09.016

Matsumoto, A., Takeishi, S., Kanie, T., Susaki, E., Onoyama, I., Tateishi, Y., et al. (2011). p57 is required for quiescence and maintenance of adult hematopoietic stem cells. Cell Stem Cell. 9, 262-271. doi: 10.1016/j.stem.2011.06.014

Menon, A. H., Soundarya, S. P., Sanjay, V., Chandran, S. V., Balagangadharan, K., and Selvamurugan, N. (2018). Sustained release of chrysin from chitosan-based scaffolds promotes mesenchymal stem cell proliferation and osteoblast differentiation. Carbohydr. Polym. 195, 356-367. doi: 10.1016/j.carbpol.2018.04.115

Miao, W., Xufeng, R., Park, M. R., Gu, H., Hu, L., Kang, J. W., et al. (2013). Hematopoietic stem cell regeneration enhanced by ectopic expression of ROSdetoxifying enzymes in transplant mice. Mol. Ther. 21, 423-432. doi: 10.1038/ mt.2012.232 
Milano, F., Gooley, T., Wood, B., Woolfrey, A., Flowers, M. E., Doney, K., et al. (2016). Cord-Blood Transplantation in Patients with Minimal Residual Disease. N. Engl. J. Med. 375, 944-953. doi: 10.1056/NEJMoa1602074

Mohammadali, F., Abroun, S., and Atashi, A. (2018). Mild hypoxia and human bone marrow mesenchymal stem cells synergistically enhance expansion and homing capacity of human cord blood CD34+ stem cells. Iran J. Basic Med. Sci. 21, 709-716. doi: 10.22038/IJBMS.2018.26820.6561

Naka, K., Muraguchi, T., Hoshii, T., and Hirao, A. (2008). Regulation of reactive oxygen species and genomic stability in hematopoietic stem cells. Antioxid. Redox Signal. 10, 1883-1894. doi: 10.1089/ars.2008.2114

Nakamura-Ishizu, A., Takizawa, H., and Suda, T. (2014). The analysis, roles and regulation of quiescence in hematopoietic stem cells. Development 141, 46564666. doi: 10.1242/dev.106575

Notta, F., Doulatov, S., Laurenti, E., Poeppl, A., Jurisica, I., and Dick, J. E. (2011). Isolation of single human hematopoietic stem cells capable of long-term multilineage engraftment. Science 333, 218-221. doi: 10.1126/science.1201219

Pagliuca, S., Ruggeri, A., and Peffault de Latour, R. (2019). Cord blood transplantation for bone marrow failure syndromes: state of art. Stem Cell Investig. 6, 39. doi: 10.21037/sci.2019.10.04

Peled, T., Shoham, H., Aschengrau, D., Yackoubov, D., Frei, G., Rosenheimer, G. N., et al. (2012). Nicotinamide, a SIRT1 inhibitor, inhibits differentiation and facilitates expansion of hematopoietic progenitor cells with enhanced bone marrow homing and engraftment. Exp. Hematol. 40, 342-355. doi: 10.1016/ j.exphem.2011.12.005

Pietras, E. M., Warr, M. R., and Passegué, E. (2011). Cell cycle regulation in hematopoietic stem cells. J. Cell Biol. 195, 709-720. doi: 10.1083/jcb.201102131

Pineault, N., Cortin, V., Boyer, L., Garnier, A., Robert, A., Thérien, C., et al. (2011). Individual and synergistic cytokine effects controlling the expansion of cord blood CD34+ cells and megakaryocyte progenitors in culture. Cytotherapy 13, 467-480. doi: 10.3109/14653249.2010.530651

Sharff, K. A., Song, W. X., Luo, X., Tang, N., Luo, J., Chen, J., et al. (2009). Heyl basic helix-loop-helix protein plays an important role in mediating BMP9induced osteogenic differentiation of mesenchymal progenitor cells. J. Biol. Chem. 284, 649-659. doi: 10.1074/jbc.M806389200

Shi, X., Li, W., Liu, H., Yin, D., and Zhao, J. (2017). The ROS/NF-кB/NR4A2 pathway is involved in $\mathrm{H} 2 \mathrm{O} 2$ induced apoptosis of resident cardiac stem cells via autophagy. Oncotarget 8, 77634-77648. doi: 10.18632/oncotarget.20747

Shin, S. Y., Kim, C. G., Jho, E. H., Rho, M. S., Kim, Y. S., Kim, Y. H., et al. (2004). Hydrogen peroxide negatively modulates Wnt signaling through downregulation of $\beta$-catenin. Cancer Lett. 212, 225-231. doi: 10.1016/j.canlet.2004.03.003

Sirin, O., Lukov, G. L., Mao, R., Conneely, O. M., and Goodell, M. A. (2010). The orphan nuclear receptor Nurr1 restricts the proliferation of hematopoietic stem cells. Nat. Cell Biol. 12, 1213-1219. doi: 10.1038/ncb2125

Takubo, K., Goda, N., Yamada, W., Iriuchishima, H., Ikeda, E., Kubota, Y., et al. (2010). Regulation of the HIF-1 alpha level is essential for hematopoietic stem cells. Cell Stem. Cell. 7, 391-402. doi: 10.1016/j.stem.2010.06.020
Testa, U., Labbaye, C., Castelli, G., and Pelosi, E. (2016). Oxidative stress and hypoxia in normal and leukemic stem cells. Exp. Hematol. 44, 540-560. doi: 10.1016/j.exphem.2016.04.012

Undi, R. B., Gutti, U., Sahu, I., Sarvothaman, S., Pasupuleti, S. R., Kandi, R., et al. (2016). Wnt Signaling: Role in Regulation of Haematopoiesis. Indian J. Hematol. Blood Transfus. 32, 123-134. doi: 10.1007/s12288-015-0585-3

Wilkinson, A. C., Ishida, R., Kikuchi, M., Sudo, K., Morita, M., Crisostomo, R. V., et al. (2019). Long-term ex vivo haematopoietic-stem-cell expansion allows nonconditioned transplantation. Nature 571, 117-121. doi: 10.1038/s41586-019-1244-x

Wilson, A., Laurenti, E., and Trumpp, A. (2009). Balancing dormant and selfrenewing hematopoietic stem cells. Curr. Opin. Genet. Dev. 19, 461-468. doi: 10.1016/j.gde.2009.08.005

Xiao, X., Lai, W., Xie, H., Liu, Y., Guo, W., Liu, Y., et al. (2019). Targeting JNK pathway promotes human hematopoietic stem cell expansion. Cell Discovery 5, 2-2. doi: 10.1038/s41421-018-0072-8

Xie, J., Briggs, J. A., and Briggs, R. C. (1998). Human hematopoietic cell specific nuclear protein MNDA interacts with the multifunctional transcription factor YY1 and stimulates YY1 DNA binding. J. Cell Biochem. 70, 489-506. doi: 10.1002/(SICI)1097-4644(19980915)70:4<489::AID-JCB6>3.0.CO;2-F

Yoshida, S., Hong, S., Suzuki, T., Nada, S., Mannan, A. M., Wang, J., et al. (2011) Redox Regulates Mammalian Target of Rapamycin Complex 1 (mTORC1) Activity by Modulating the TSC1/TSC2-Rheb GTPase Pathway. J. Biol. Chem. 286, 32651-32660. doi: 10.1074/jbc.M111.238014

Yu, L., Shi, Z., Gao, L., and Li, C. (2015). Mitigated reactive oxygen species generation leads to an improvement of cell proliferation on poly[glycidyl methacrylate-co-poly(ethylene glycol) methacrylate] functionalized polydimethylsiloxane surfaces. J. Biomed. Mater. Res. A. 103, 2987-2997. doi: 10.1002/jbm.a.35432

Zhang, Y., and Gao, Y. (2016). Novel chemical attempts at ex vivo hematopoietic stem cell expansion. Int. J. Hematol. 103, 519-529. doi: 10.1007/s12185-016-1962-x

Zhang, W. S., Fan, S. B., Song, H. N., Ding, Y. H., He, M., Yang, M., et al. (2019). Screening and Verification of Antioxidant Small Molecular Compounds for Expansion of Human Hematopoietic Stem Cells Ex Vitro. Zhongguo Shi Yan Xue Ye Xue Za Zhi 27, 585-593. doi: 10.19746/j.cnki.issn1009-2137.2019.02.045

Conflict of Interest: The authors declare that the research was conducted in the absence of any commercial or financial relationships that could be construed as a potential conflict of interest.

Copyright (c) $2020 \mathrm{Li}, \mathrm{He}$, Zhang, Yang, Ding, Xu, Gu, Li, Yin and Gao. This is an open-access article distributed under the terms of the Creative Commons Attribution License (CC BY). The use, distribution or reproduction in other forums is permitted, provided the original author(s) and the copyright owner(s) are credited and that the original publication in this journal is cited, in accordance with accepted academic practice. No use, distribution or reproduction is permitted which does not comply with these terms. 